\title{
MÎQÂT MAKÂNÎ JEMAAH HAJI INDONESIA MENURUT KEMENTERIAN AGAMA DAN ORGANISASI PERSATUAN ISLAM
}

\author{
Muhammat Nuri \\ University of Malaya \\ Wilayah Persekutuan Kuala Lumpur, Malaysia \\ E-mail: tguhnurani@yahoo.com
}

\begin{abstract}
Indonesian Hajj Mîqât Makânî According to the Ministry of Religious Affairs and the Persatuan Islam (PERSIS). Haji is one of the worship that takes place every year. A Muslim is required to perform the pilgrimage only one time in his life when he was able. As the general character of figh, the hajj fiqh was not immune from the differences of opinion. One of the differences of opinion in the Hajj for pilgrims Indonesia is the difference in determining mîqa $t$ makânî. Two religious institutions, the Ministry of Religious Affairs and the Persatuan Islam (PERSIS) have different opinions on this. This difference is because the Indonesian pilgrims are in the plane as it passes through a predetermined mîqât makânî.
\end{abstract}

Keywords: Hajj, Umrah, mîqât makânî, fiqh

\begin{abstract}
Abstrak: Mîqât Makânî Jemaab Haji Indonesia Menurut Kementerian Agama dan Organisasi Persatuan Islam. Ibadah haji merupakan salah satu ibadah yang dilaksanakan setiap tahun. Seorang Muslim hanya diwajibkan melaksanakan ibadah haji satu kali dalam hidupnya apabila ia mampu. Sebagaimana karakter fikih secara umum, fikih dalam ibadah haji juga tidak luput dari adanya perbedaan pendapat (ikhtilâf). Salah satu perbedaan pendapat dalam ibadah haji untuk jemaah Indonesia adalah perbedaan dalam menentukan mîqât makânî (tempat memulai) ibadah haji. Dua lembaga yang mengurus masalah keagamaan di Indonesia yaitu Kementerian Agama dan organisasi Persatuan Islam (PERSIS) berbeda pendapat tentang hal ini. Perbedaan ini disebabkan karena jemaah haji Indonesia sedang berada dalam pesawat saat melewati mîqât makânî yang telah ditetapkan.
\end{abstract}

Kata Kunci: haji, umrah, mîqât makânî, fikih

\section{Pendahuluan}

Dalam Islam, ibadah haji merupakan ibadah yang sangat penting karena merupakan bagian dari rukun Islam. Ibadah haji bukan merupakan syariat baru tetapi ia merupakan syariat lama yang telah dilaksanakan oleh umat-umat terdahulu sebelum kedatangan Rasulullah Saw. Sebagian besar manasik haji diambil dari apa yang dicontohkan oleh Nabi Ibrahim As.

Pelaksanaan haji dalam Islam mempunyai peranan yang signifikan karena merupakan salah satu syarat mutlak untuk menentukan keislaman seseorang. Seorang Muslim yang telah memenuhi syarat dan mempunyai kemampuan maka wajib melaksanakan ibadah haji. Jika tidak melaksanakan haji, Rasulullah Saw. memberikannya dua pilihan yaitu meninggal dalam keadaan yahudi atau nasrani.

Naskah diterima: 15 September 2013, direvisi: 25 Oktober 2013, disetujui untuk terbit: 30 November 2013.
Pada dasarnya kewajiban menunaikan ibadah haji merupakan kewajiban yang bersifat individu. Namun dalam pelaksanaannya, ibadah haji merupakan bagian dari tugas dan tanggung jawab pemerintah. Pemerintah mempunyai tanggung jawab untuk mengatur pelaksanaan ibadah haji agar berjalan dengan baik dan tertib. Apabila pemerintah tidak melaksanakan hal ini berarti telah mengabaikan urusan umat Islam.

Dalam melaksanakan syariat Islam, khususnya ibadah haji, merupakan suatu keniscayaan apabila terjadi perbedaan pendapat atau ikhtilâf. Perbedaan pendapat merupakan karakter dari fikih. Perbedaan pendapat terjadi karena adanya keragaman dalam metode istinbâth hukum dari Alquran dan Sunah. Dari perbedaan pendapat ini kemudian muncul pelbagai aliran atau mazhab dalam hukum Islam. Pada dasarnya acuan semua mazhab adalah Alquran dan Sunah.

Perbedaan pendapat dalam fikih atau ikhtilâf merupakan persoalan yang terjadi dalam realitas 
kehidupan manusia. Hal ini senantiasa akan terjadi dan tidak akan pernah selesai. Yang menjadi urgen untuk orang Muslim adalah bagaimana menyikapi perbedaan pendapat tersebut.

Ikhtilâf merupakan term dari bahasa Arab yang berarti berselisih atau tidak sepaham. Adapun dalam terminologi fikih, ikhtilâf diartikan sebagai perbedaan paham atau pendapat di kalangan para ulama fikih sebagai hasil dari ijtihad untuk mendapatkan atau menetapkan suatu ketentuan hukum tertentu ${ }^{1}$. Perbedaan pendapat akan senantiasa terjadi karena pola pemikiran manusia terus berkembang.

Dalam masalah haji, khususnya jemaah haji Indonesia, yang senantiasa menjadi perdebatan adalah tempat untuk memulai ibadah haji atau mîqât makânî. Hal ini dianggap sebagai sesuatu yang urgen karena pelaksanaan ibadah haji harus dimulai dari tempat tertentu yang ditentukan oleh syariat. Jemaah haji Indonesia berada di wilayah mîqât makânı̂ ketika mereka berada dalam pesawat. Hal ini kemudian menimbulkan perbedaan pendapat tentang waktu mulai melakukan ihram.

Tulisan ini akan mengkaji tentang perbedaan pendapat (ikhtilâf) antara Kementerian Agama Republik Indonesia (Kemenag RI) dan Organisasi Persatuan Islam (PERSIS) dalam masalah mîqât makânî untuk jemaah haji Indonesia.

\section{Metode ljtihad Kemenag RI dan PERSIS}

Kementerian Agama (dulu disebut Departemen Agama) didirikan antara lain dengan tujuan untuk melaksanakan tuntutan UUD 1945 pasal 29 yang menyebutkan bahwa "Negara berdasarkan Ketuhanan Yang Maha Esa" dan "Negara menjamin kemerdekaan tiap-tiap penduduk untuk memeluk agamanya masing-masing dan beribadah menurut agama dan kepercayaannya itu". Tugas Kementerian Agama adalah untuk menjamin terlaksananya hal tersebut dengan sebaik-baiknya.

Tugas utama Kementerian Agama meliputi²: (1) Pelayanan keperluan dan kepentingan umat beragama dalam menjalankan dan mengembangkan agama mereka dan (2) Pemeliharaan dan pengembangan kesejahteraan hidup antar umat pelbagai agama.

Berkaitan dengan tugas pertama, Kementerian Agama melakukan hal-hal sebagai berikut ${ }^{3}$ : (1)

\footnotetext{
${ }^{1}$ M. Ali Hasan, Perbandingan Mazhab, (Jakarta: PT Raja Grafindo Persada, 2002), h. 114.

${ }^{2}$ Departemen Agama, 27 Tahun Departemen Agama (3 Januari 1973), (t.tp.: Panitia HUT ke XXVII, t.t.), h. 12.

${ }^{3}$ Departemen Agama, 27 Tahun Departemen Agama (3 Januari 1973), h. 12-13.
}

Memberikan pelayanan kepada masyarakat beragama dalam menjalankan kewajiban agama dengan baik dan teratur, seperti dalam pendidikan agama, pengembangan ibadah sosial, penyelenggaraan haji dan kunjungan ke tempat-tempat suci lainnya; (2) Memberikan bimbingan kepada bangsa Indonesia dalam pelaksanaan dan pengembangan kehidupan beragama sesuai dengan keyakinan dan ajaran agama masing-masing. Dalam hal ini pemerintah (Kementerian Agama) tidak mencampuri masalah intern keagamaan, baik yang berkaitan dengan sistem keyakinan, prinsip-prinsip kepercayaan maupun tata cara beribadah; (3) Memberikan dorongan kepada umat beragama dalam mengembangkan aktifitas yang bersifat kreatif dan konstruktif serta mengurangi sikap ketergantungan diri yang besar pada pemerintah; dan (4) Memberikan rangsangan (stimulation) kepada umat beragama untuk memperluas dimensi penghayatan keagamaan mereka, dari yang terlalu bersifat ritual menjadi penghayatan keagamaan yang lebih bersifat sosial. Hal ini dapat dirasakan manfaatnya untuk kepentingan masyarakat luas dan perkembangan agama itu sendiri dalam menghadapi masyarakat yang senantiasa berkembang secara dinamis sehingga tercipta hubungan yang harmonis antara agama dan tuntutan masyarakat.

Adapun untuk tugas kedua, Kementerian Agama melakukan usaha-usaha ${ }^{4}$ : (1) Mempersiapkan prasarana mental dan sosial untuk menumbuhkan saling pengertian dan rasa percaya antara umat pelbagai agama; dan (2) Mewujudkan platform bersama bagi kerjasama pelbagai agama.

Dalam metode istinbâth hukum, secara garis besar Kementerian Agama lebih cenderung berpedoman pada Mazhab Syâfi'î yang menjadikan Alquran, Hadis, ijmak dan qiyas sebagai landasan hukum. Imâm Syâfî̂ telah menyusun dasar-dasar istinbâth hukumnya dalam kitab al-Risâlah ${ }^{5}$. Dasar-dasar istinbâth hukum tersebut beliau praktekkan dalam ijtihadnya. Salah satu keistimewaan Mazhab Syâfi'î adalah bahwa dasar-dasar fikihnya diperkuat oleh pelbagai dalil. Sebagian dasar fikih Mazhab Syâfi'î merupakan rangkaian dari ijtihad beliau yang ada dalam kitab al-Umm.

Dasar hukum yang digunakan Imâm Syâfî̀ dalam melakukan ijtihad adalah: 6 pertama, Alquran. Imâm Syâfî̀ berhujjah dengan zahir nas Alquran selama tidak ada dalil yang menunjukkan bahwa makna

\footnotetext{
${ }^{4}$ Departemen Agama, 27 Tahun Departemen Agama (3 Januari 1973), h. 13.

${ }^{5}$ Badran Abû al-Aynayn, Ushûl al-Fiqh al-Islâmî, (Iskandariyah: Mu'assasah Syabâb al-Jâmi'ah, t.t.), h. 139.

${ }^{6}$ M. Ali Hasan, Perbandingan Mazhab, h. 211-212.
} 
yang dimaksud bukan makna zahir tersebut ${ }^{7}$. Dalam hukum Islam, Alquran dan Sunah menempati posisi yang sama sehingga tidak mungkin dapat mengkaji Alquran tanpa mengkaji Sunah yang fungsinya antara lain untuk menafsirkan Alquran. Sebagian hukum yang dibawa Alquran bersifat umum dan Sunah yang akan menjelaskan dan menguraikan hukum tersebut.

Kedua, Sunah. Imâm Syâfî̀ terkenal sebagai ulama penegak Sunah. Beliau menjadikan Hadis sebagai hujjah walaupun derajatnya adalah khabar wâhbid selama Hadis tersebut diriwayatkan oleh perawi yang tsîqat, dzâbith dan sanadnya bersambung sampai kepada Rasulullah Saw. ${ }^{8}$ Beliau tidak mensyaratkan penerimaan khabar wâhbid sebagai hujjah dengan adanya penguatan dari kebiasaan ('amal) penduduk Madinah sebagaimana pendapat Imâm Mâlik atau mensyaratkan harus riwayat masyhîr sebagaimana pendapat Imâm Abû Hanîfah'. Mazhab fikih yang dibawa oleh Imâm Syâfîî merupakan mazhab Hadis yang bersumber dari Hijaz, Irak dan Mesir. Semua Hadis dapat diterima selama sanadnya sahih dan bersambung. Imâm Syâfi'î tidak menjadikan Hadis mursal sebagai dalil kecuali Hadis mursal yang berasal dari Sa'îd ibn al-Musayyab ${ }^{10}$. Beliau tidak sepakat dengan pendapat yang menyatakan bahwa Hadis ahad tidak dapat dijadikan hujjah dan hanya menerima Hadis mutawâtir atau masyhur saja.

Ketiga, ijmak (kesepakatan para ulama). Menurut Imâm Syâfî̀, ijmak yang paling utama adalah ijmak yang dilakukan oleh para sahabat. Ijmak para sahabat mempunyai kedudukan yang paling utama karena para sahabat mendengar syariat Islam langsung dari Rasulullah Saw. Posisi selanjutnya adalah ijmak yang dilakukan oleh seluruh umat Islam di dunia. Ijmak lebih dulu diamalkan dari pada khabar wâhid. Beliau tidak menjadikan ijmak yang dilakukan oleh sebagian kaum Muslimin sebagai $\underline{\text { hujjah }}{ }^{11}$.

Keempat, qiyas yaitu menyamakan hukum masalah baru dengan hukum masalah serupa yang telah terjadi lebih dulu atau telah disebutkan hukumnya dalam Alquran dan Sunah ${ }^{12}$. Qiyas yang diterima adalah qiyas

\footnotetext{
${ }^{7}$ Badran Abû al-Aynayn, Ushôl al-Fiqh al-Islâmî, h. 139.

8 'Abd al-Wadûd Muhammad al-Siryati, Târîkh al-Figh al-Islâmî wa Nazhariyyatuhu al-Âmmah, (Beirût: Dâr al-Nahdhah al-Arabiyyah, 1993), h. 167

${ }^{9}$ Husayn Hâmid Hasan, al-Madkhal li Dirâsah al-Figh al-Islâmî, (Kaherah: Dâr al-Nahdhah al-'Arabiyyah, 1972), h. 104-106.

${ }^{10}$ Muhammad 'Alî al-Sâyis, Târîkh al-Fiqh al-Islâmî, (Damshiq: Dâr al-Fikr, 1999), h. 191.

11 'Abd al-Wadûd Muhammad al-Siryati, Târîkh al-Figh al-Islâmî, h. 168 dan Mannâ' Khalîl al-Qaththân, Târîkh al-Tasyrî' al-Islâmî, (Beirût: Mu’assasah al-Risâlah, 1993), h. 374.

12 Sirajuddin Abbas, Sejarah dan Keagungan Madzhab Syafi'i, (Jakarta: CV Pustaka Tarbiyah, 2006), h. 166 dan 168.
}

terhadap ashl saja dengan syarat bahwa ashl tersebut bersumber dari Alquran atau Sunah ${ }^{13}$. Menurut Imâm Syâfi'î qiyas dan ijtihad mempunyai pengertian yang sama. Jumhur ulama sepakat bahwa qiyas dapat dijadikan hujjah dan sebagai sumber hukum syarak ${ }^{14}$. Qiyas hanya dapat diaplikasikan terhadap masalah yang berhubungan dengan muamalat karena masalah yang berhubungan dengan ibadah telah sempurna dijelaskan dalam Alquran dan Sunah. Oleh karena itu maka ada kaidah bahwa tidak ada qiyas dalam hukum ibadah ${ }^{15}$.

Metodologi pengambilan istinbâth hukum dalam Mazhab Syâfî̀ yang dijadikan pegangan oleh Kementerian Agama dalam fungsinya sebagai pelaksana bimbingan ibadah haji maupun ibadah-ibadah lainnya adalah: (1) Mencari dalil atau keterangan dari Alquran, termasuk meneliti tafsir bi al-ma'tsûr dan tafsir bi almáqûl al-mahmûd; (2) Bila tidak terdapat dalil Alquran maka bersandar pada keterangan atau dalil dari Sunah; (3) Jika tidak terdapat dalil dari Sunah maka mencari dalil dari ijmak para sahabat dan ulama; (4) Jika tidak terdapat dalil dari ijmak maka pengambilan istinbâth hukum didasarkan pada qiyas.

Persatuan Islam (PERSIS) adalah sebuah organisasi Islam di Indonesia yang didirikan pada tanggal 12 September 1923, bertepatan dengan tanggal 1 Safar $1342 \mathrm{H}$ di Bandung. PERSIS didirikan dengan tujuan untuk memberikan pemahaman Islam yang asli sebagaimana yang dibawa oleh Rasulullah Saw. PERSIS mempunyai pandangan yang berbeda dari pemahaman Islam tradisional yang dianggap sudah tidak asli karena bercampur dengan budaya setempat, sikap taklid buta, bidah, khurafat, musyrik, sikap tidak kritis dan tidak mau menggali Islam lebih dalam dengan mengkaji kitabkitab Hadis yang sahih. Melalui para ulamanya, seperti Ahmad Hassan Bangil, PERSIS mencoba menjelaskan makna Islam yang sebenarnya. PERSIS menjelaskan Islam hanya yang bersumber dari Alquran dan Hadis ${ }^{16}$.

PERSISbukanorganisasikeagamaanyangberorientasi politik namun lebih fokus terhadap pendidikan Islam dan dakwah serta berusaha menegakkan ajaran Islam secara utuh tanpa dicampuri oleh khurafat, syirik dan bidah yang telah banyak menyebar di kalangan umat Islam. Prinsip-prinsip perjuangan kembali pada Alquran dan Sunah menjadi visi dan misi atau trademark PERSIS sebagaimana yang tercantum dalam

\footnotetext{
${ }^{13}$ Muhammad 'Alî al-Sâyis, Târîkhh al-Fiqh al-Islâmî, h. 191.

${ }^{14}$ Abdul Latif Muda, Perbahasan Sejarah Perundangan Islam dan Mazhab Fiqh, (Kuala Lumpur: Pustaka Salam Sdn. Bhd, 2003), h. 340 .

${ }^{15}$ M. Ali Hasan, Perbandingan Mazhab, h. 212.

16 "Persatuan Islam" dalam kd.wordpress.com/tag/sejarah-persis), diunduh 2 Agustus 2013.
} 
Qanun Asasi (Anggaran Dasar) dan Qanun Dakhili (Anggaran Rumah Tangga) PERSIS yang dirumuskan dalam Rencana Jihad pada Qanun Asasi 1957 Bab II pasal 1 mengenai Perancangan Jihad Umum ${ }^{17}$.

Dalam Qanun Asasi PERSIS yang dihasilkan Muktamar tahun 2000 di Jakarta, misi PERSIS yang bertujuan untuk terlaksananya syariat Islam berdasarkan Alquran dan Sunah secara kâffah dalam segala aspek kehidupan dijelaskan lebih terperinci pada pasal 5 tentang Jihad sebagai berikut: (1) Mengembangkan dan memberdayakan potensi jamizyah demi terwujudnya jamizyyah sebagai sûrah musaghgharah 'an al-Islâm wa hikmatuhu al-asmâ'; (2) Meningkatkan pemahaman dan pengamalan keislaman bagi anggota khususnya dan umat Islam pada umumnya sehingga tercipta barisan ulama, zu'amấ, ash $\underline{h} a \hat{b}$, dan $\underline{h} a w a \hat{r} i y y \hat{u} n$ Islam yang senantiasa iltizâm terhadap risalah Allah Swt.; (3) Meningkatkan kesadaran dan pemberdayaan anggota khususnya dan umat Islam umumnya dalam bermuamalat secara jamẩi dalam setiap aspek kehidupan.

PERSIS merupakan organisasi yang tidak bermazhab atau tidak mengikatkan diri pada salah satu imam mazhab yang muktabar. PERSIS berasaskan pada keyakinan bahwa hidup harus sesuai dengan Alquran dan Sunah ${ }^{18}$.

Mekanisme ijtihad di kalangan PERSIS dilakukan seperti yang ditempuh oleh para sahabat dan imam mazhab. Dengan kata lain, metodologi pengambilan istinbâth hukum adalah sebagai berikut: (1) Mencari dalil dari Alquran termasuk meneliti tafsir bi al-ma'tsûr dan tafsir bi al-máqûu al-mahnûd. Bila terdapat perbedaan pemahaman dan penafsiran maka dilakukan penelitian secara sungguh-sungguh. Dan kalau dianggap perlu maka diadakan al-tarjîh atau tharîqah al-jam'ï; (2) Bila tidak terdapat dalil Alquran maka mencari keterangan atau dalil dari sunnah. Bila ada perbedaan pendapat maka diadakan kajian Hadis, baik dari segi sanad maupun matan sebagai langkah untuk melakukan pentarjîh $\underline{h}$-an; (3) Jika tidak terdapat dalil dari Sunah maka dicari dalil yang bersumber dari atsar sahabat dengan syarat tidak bertentangan dengan Alquran dan Sunah sahih, termasuk di dalamnya ijmak sahabat; (4) Jika tidak terdapat dalil dari Alquran, Sunah atau atsar sahabat maka menggunakan metode qiyas, istih $\underline{b} a \hat{n}$ dan mashlabah mursalah dalam masalah-masalah sosial.

${ }^{17}$ Uyun Kamiluddin, Ijtihad sebagai Satu Usaha Penggali Hukum Islam dan Peranannya dalam Pembinaan Hukum Islam, Skripsi Fakultas Syariah, UNISBA, 1985, h. 70.

18 Aceng Zakaria, "Makna Ahlussunnah Waljamaah", dalam Kumpulan Keputusan Sidang Dewan Hisbah Persatuan Islam (PERSIS) tentang Akidah dan Ibadah, ed. Wawan Shofwan Shalehuddin, (Bandung: Persis Pers, 2008), h. 28.
Dalam masalah ibadah mahdhah digunakan kaidah "semua dilarang kecuali yang diperintahkan", sedangkan dalam urusan sosial keduniaan digunakan kaidah "semua boleh kecuali yang dilarang". Selain itu juga digunakan petunjuk dalam masalah keduniawian yaitu 'antum a'lam bi umûr dunyâkum'. Metode 'urftermasuk dalam kaidah ini sehingga boleh dilakukan selama tidak bertentangan dengan Alquran dan Sunah ${ }^{19}$.

Mekanisme ijtihad yang dilakukan para ulama PERSIS untuk melayani keperluan masyarakat dalam memecahkan masalah keagamaan telah mendorong dibentuknya majelis ulama yang disebut Dewan Hisbah. Secara organisasi majelis ini merupakan otonomi PERSIS ${ }^{20}$.

Metode istidlâl (pengambilan dalil) dari Alquran yang dilakukan oleh Dewan Hisbah adalah: (1) Mendahulukan zahir ayat Alquran daripada takwil dan memilih cara-cara tafwidh dalam masalah yang berhubungan dengan ittiqâdiyyah; (2) Menerima dan menyakini isi kandungan Alquran sekalipun jelas bertentangan dengan 'aqlî dan 'âdî, seperti peristiwa isra dan mikraj; (3) Mendahulukan makna haqî $q \hat{\imath}$ daripada majâzî kecuali jika ada alasan (qarinah); (4) Apabila ayat Alquran bertentangan dengan Hadis maka didahulukan ayat Alquran sekalipun Hadis tersebut diriwayatkan oleh muttafaq 'alayh; (5) Menerima adanya nâsikh dalam Alquran dan tidak menerima adanya ayat-ayat yang mansûkh (nâsikh al-kulli); (6) Menerima tafsir dari para sahabat dalam memahami ayat-ayat Alquran (tidak hanya penafsiran abl al-bayt) dan mengambil penafsiran sahabat yang lebih ahli jika terjadi perbedaan pentafsiran di kalangan para sahabat; (7) Mengutamakan tafsir bi al-ma'tsûr daripada bi alray; (8) Menerima Hadis sebagai penjelasan terhadap Alquran kecuali ayat-ayat yang telah diungkapkan dengan sîghah al-bishr seperti ayat mengenai makanan yang diharamkan. ${ }^{21}$

Dalam beristidlâl dengan Hadis, Dewan Hisbah menempuh langkah-langkah sebagai berikut: (1) Menggunakan Hadis sahih dan hasan dalam mengambil keputusan hukum; (2) Menerima kaidah al-hadìts al-dha'îfyuqwâ ba'dhuhu ba'dhan, jika kedaifan Hadis tersebut dari segi hafadzan râwî̀ (dzâbith) dan tidak bertentangan dengan Alquran atau Hadis lain

\footnotetext{
${ }^{19}$ Uyun Kamiluddin, Ijtihad Sebagai Satu Usaha Penggali Hukum Islam, h. 80-81.

${ }^{20}$ Syamsul Falah, Pandangan Keagamaan Persatuan Islam: Studi atas Fatwa-Fatwa Dewan Hisbah Tahun 1983-1997", Laporan Penelitian IAIN Sunan Goenoeng Djati, Bandung, 1998, h. 47.

${ }^{21}$ Uyun Kamiluddin, Menyorot Ijtihad Persis: Fungsi dan Peranan dalam Pembinaan Hukum Islam di Indonesia, (Bandung: Tafakur, 2006), h. 81-82.
} 
yang sahih. Jika daifnya itu dari segi fisq al-râwî atau tertuduh dusta maka kaidah itu tidak dipakai; (3) Tidak menerima kaidah al-hadîts al-dha'îf yu'mal fî fadhầil al'amal karena yang menunjukkan fadhâil al-'amal dalam Hadis sahih pun banyak; (4) Menerima Hadis sahih sebagai tasyrî̀ yang berdiri sendiri sekalipun bukan merupakan penjelasan dari Alquran; (5) Menerima Hadis ahad sebagai dasar hukum selama Hadis tersebut sahih; (6) Hadith mursalsahabat dan mawqûffbi al- $\underline{\text { hukm }}$ dipakai sebagai hujjah selama sanad Hadis tersebut sahih dan tidak bertentangan dengan Hadis yang sahih; (7) Hadis mursal tâbi î dijadikan hujjah bila Hadis tersebut disertai oleh qarînah yang menunjukkan ittishâlnya Hadis tersebut; (8) Menerima kaidah al-jar $\underline{h}$ muqaddam 'alâ al-ta'dîl dengan ketentuan jika yang melakukan jarh menjelaskan jar $\underline{h}$ nya maka didahulukan daripada $t a^{\prime} d \hat{\imath} l$. Jika yang melakukan jar $\underline{h}$ tidak menjelaskan sebab jar $\underline{h}$ ya maka didahulukan tádîl daripada jarh . Dan jika yang melakukan jar $\underline{h}$ tidak menjelaskan sebab jarhnnya tetapi tidak seorang pun yang menyatakan tsîqah maka jarhnya boleh diterima; (9) Menerima kaidah mengenai sahabat "al-shabâabah kulluhum 'udîl"; (10) Riwayat orang yang suka melakukan tadlîs diterima jika ia menerangkan bahwa apa yang diriwayatkannya itu jelas sîghat tahammulnya menunjukkan ittishâl seperti menggunakan kata 'haddatsaniّ22.

Dalam masalah-masalah yang tidak ditemukan nas

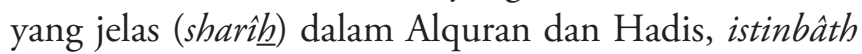
hukum ditempuh dengan jalan ijtihad jamầ rumusannya sebagai berikut: (1) Tidak menerima ijmak mutlak dalam urusan ibadah kecuali ijmak sahabat; (2) Tidak menerima qiyas dalam masalah ibadah mabhdhah sedangkan dalam masalah ghayr mabdhah qiyas diterima selama memenuhi persyaratan qiyas; (3) Dalam memecahkan ta'arudh al-adillah diupayakan dengan cara: (a) tharîqah al-jam'i, selama masih mungkin di-jam; b) tharîq al-tarjîh dari pelbagai aspek, misalnya mendahulukan yang mutsbit daripada al-nafi', mendahulukan Hadis-Hadis riwayat shahîhayn daripada yang lainnya dalam masalah-masalah tertentu. Maka Hadis yang diriwayatkan oleh Imâm Muslim lebih didahulukan daripada riwayat al-Bukhârî seperti dalam hal pernikahan Nabi Saw. dengan Maymûnah, meninggalkan sesuatu yang dikhawatirkan akan terjatuh pada hukum bidah lebih didahulukan daripada mengamalkan sesuatu yang diragukan Sunahnya; c) tharîah al-naskh yaitu jika diketahui mana yang lebih dulu dan mana yang belakangan, misalnya dalam membahas masalah ijtihad maka Dewan Hisbah menggunakan kaidah-kaidah ushul fikih

${ }^{22}$ Uyun Kamiluddin, Menyorot Ijtihad Persis, h. 82-83. sebagai lazimnya para fukaha. Dewan Hisbah tidak mengikatkan diri pada suatu mazhab tetapi pendapat imam mazhab menjadi bahan pertimbangan dalam mengambil ketentuan hukum sepanjang sesuai dengan Alquran dan Sunah ${ }^{23}$.

Dengan demikian maka Kementerian Agama dalam istinbâth hukum berdasarkan Alquran, Sunah, ijmak dan qiyas; sedangkan PERSIS menolak dasar hukum ijmak dan qiyas. Dalam pandangan A. Hassan dan ulama PERSIS lainnya ijmak dan qiyas bukan sumber hukum tetapi hanya merupakan salah satu cara untuk menentukan hukum ${ }^{24}$.

\section{Mîqât Makânî dalam Ibadah Haji}

Mîqât makânî dalam haji adalah tempat yang telah ditentukan untuk berniat ihram haji ${ }^{25}$. Dari batas-batas tempat ini seseorang yang akan melaksanakan ibadah haji melakukan ihram dan berniat haji.

Apabila dilihat dari sudut geografis, dalam masalah mîqât makânî haji umat Islam terbagi menjadi dua kelompok. Kelompok pertama adalah umat Islam yang tinggal di dalam wilayah kota Mekah atau tempat tinggalnya kurang dari batas mîqât. Mîqât jemaah haji yang tinggal di kota Mekah adalah dari kota Mekah itu sendiri. Ia boleh melaksanakan ihram dari rumahnya, tetapi lebih utama adalah dari mesjid yang ada di sekitar rumahnya. Orang yang tempat tinggalnya terletak antara kota Mekah dan mîqât maka mîqât makânînya adalah di daerah tempat tinggalnya itu seperti penduduk kota Jeddah yang terletak sekitar $75 \mathrm{~km}$ dari Mekah dan penduduk Bashrah yang terletak sekitar $45 \mathrm{~km}$ dari Mekah $^{26}$.

Kelompok kedua adalah yang disebut al-âfaqî, yaitu orang-orang yang bukan penduduk kota Mekah dan tempat tinggalnya di luar mîqât. Syaykh Ismầil, Abû al-'Abbâs dan Ahmad al-'Umanî berpendapat ${ }^{27}$ bahwa orang yang telah tinggal di Mekah satu tahun maka mîqât hajinya di bawah pancuran emas dan mîqât umrahnya di Tan'îm. Mîqât makânî kelompok al-âfaqî̀ adalah di beberapa tempat yang telah ditentukan.

Ada lima tempat yang telah ditentukan sebagai mî̀ât

\footnotetext{
${ }^{23}$ Dede Rosyada, Metode Kajian Hukum Dewan Hisbah PERSIS, (Jakarta: Logos, 1999), h. 89.

${ }^{24}$ Ahmad Hassan Bandung, Ijmak-Qiyas-Mazhab-Taqlid, (Bangil: Lajnah Penerbitan Pesantren PERSIS, 1984), h. v-vi.

${ }^{25}$ Muhammad ibn Ismầ̂l Dâwud al-Fatanî, Mathla’ al-Badrayn wa Majma' al-Bahrayn, (t.tp.: Maktabah wa Mathba'ah Muhammad al-Nahd wa Aulâduh, t.t), h. 67-68.

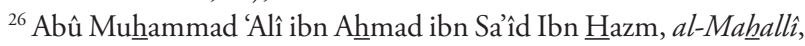
(t.tp. Dâr al-Fikr, t.t), h. 71.

${ }^{27}$ Muhammad ibn Yûsuf ibn 'Îsâ, Syarh al-Nayl wa Syifầ al-Alîl, (t.tp.: Maktabah al-Irsyâd, t.t.), h. 23.
} 


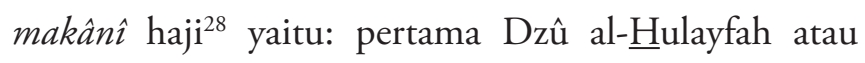
Bir 'Ali' ${ }^{29}$. Mîqât ini adalah untuk penduduk wilayah kota Madinah atau mereka yang melalui wilayah ini walaupun bukan penduduk kota Madinah. Mîqât tersebut merupakan yang paling jauh diantara mîqâtmîqât lain dari Mekah. Di daerah ini dibangun mesjid tempat dimana Rasulullah Saw. melakukan ihram haji dan umrah.

Kedua, Juhfah ${ }^{30}$. Saat ini tempat mîqât di Juhfah dalam keadaan rusak sehingga orang melaksanakan ihramnya dari daerah Râbigh yang berada sedikit lebih jauh sebelum Juhfah. Jaraknya dengan Mekah adalah sekitar $204 \mathrm{~km}$. Mîqât itu untuk jemaah umrah dan haji penduduk Syam (negara-negara Syria, Lebanon, Jordan, dan Palestin), Mesir, Sudan, negara-negara Arab Bagian Barat (Aljazair, Tunis, Libya, Maroko, Mauritania) dan negara-negara Afrika (Senegal, Nigeria, Kamerun, Somalia, Uganda dan Afrika Selatan). Selain mereka, jemaah umrah dan haji yang tidak melalui wilayah Madinah melakukan ihram dari mîqât ini.

Ketiga, Yalamlam ${ }^{31}$. Mîqât ini untuk penduduk Yaman dan jemaah umrah atau haji selain penduduk Yaman tetapi melalui wilayah Yaman. Jarak mîqât ini dari kota Mekah sekitar $120 \mathrm{~km}$. Jemaah yang melakukan ihram dari mîqât ini termasuk jemaah haji dan umrah dari Malaysia, Tiongkok, Indonesia, Pakistan dan Asia Selatan.

Keempat, Qarn al-Manâzil al-Say ${ }^{32}$. Jaraknya dari kota Mekah sekitar $75 \mathrm{~km}$. Mîqât ini untuk penduduk wilayah Najd (Riyadh dan sekitarnya). Jemaah haji dan umrah dari wilayah timur Saudi Arabia dan negara-

${ }^{28}$ Zakariyyâ ibn Muhammad ibn Ahmad ibn Zakariyyâ al-Anshârî, Fath al-Wahhâb bi Syarh Minhâj al-Thullâb, (Beirût-Lubnân: Dâr alKutub al-'Ilmiyyah, 1998), h. 237-238.

${ }^{29}$ Tempat ini terletak hanya $10 \mathrm{~km}$ dari Madinah dan jauhnya dari

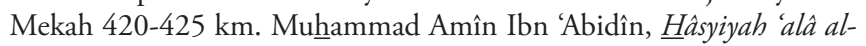
Durr al-Mukhtâr Syarh Tanwîr al-Abshâr fi Fiqh Madzhab al-Imâm Abî Hanîfah al-Nưmân, (Beirût: Dâr al-Fikr, t.t.), Jilid II, h. 522.

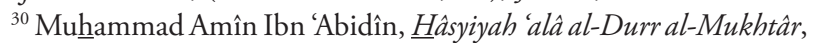
h. 522 .

${ }^{31}$ Yalamlam dikenal dengan panggilan al-Sa'diyyah yaitu miqâtnya penduduk Yaman dan negara-negara di sebelah selatannya yang satu arah atau negara-negara sebelah Asia. Jaraknya kurang lebih 95-100 km sebelah selatan kota Mekah. Di sana terdapat masjid kuno tetapi setelah ada jalan yang menghubungkan Mekah dengan Jazan melalui al-Layts maka agak susah mencapai masjid tersebut. Oleh karena itu untuk memudahkan para jemaah haji dan mu'tamirin maka dibangunlah masjid baru di depan arah miqât sebelah barat atau kira-kira 21 $\mathrm{km}$ barat daya masjid lama sehingga jaraknya dari Masjidil Haram sekitar 130 km. Muhammad Ilyâs 'Abd al-Ghânî, Târîkh Makkah alMukarramah: Sejarah Makkah, terj. Anang Rikza Mesyhadi (Madinah Munawwarah: al-Rasheed Printers, t.t.), h. 34.

${ }^{32}$ Karena ada dua jalan utama menuju Mekah maka batas miqât dan ihram ditentukan dengan membangun dua masjid sebagai tanda untuk setiap jalan, yaitu yang dikenal dengan miqât al-sayl al-kabîr dan miqât wâdî mahram. negara Teluk (Kuwait, Qatar, Bahrain, Oman, Emirat), jemaah haji dari Iran dan negara lainnya mengambil ihram dari mîqât ini.

Kelima, Dzât 'Irq yaitu mîqât untuk penduduk Irak. Jarak Dzât 'Irq dengan kota Mekah sekitar $94 \mathrm{~km}^{33}$.

Mîqât-mîqât tersebut ditentukan oleh Rasulullah Saw. seperti yang dijelaskan dalam Hadis dari Ibn 'Abbâs Ra:

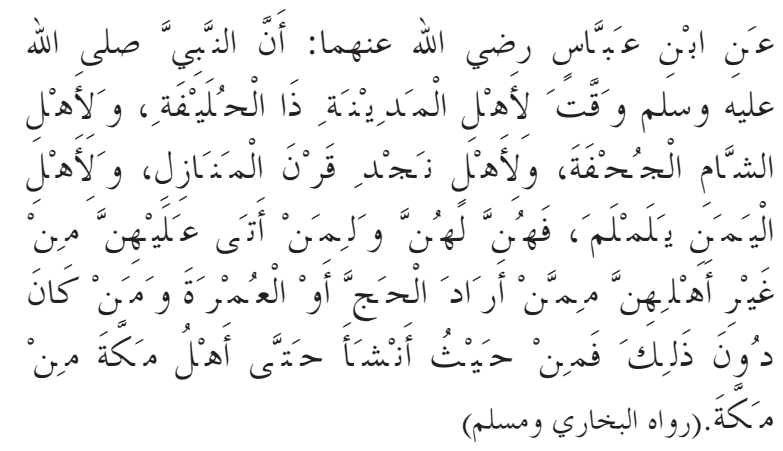

Dari Ibn 'Abbâs Ra. bahwasannya Rasulullah Saw. telah menentukan mîqât bagi penduduk Madinah Dzû alHulayfah, bagi penduduk Syam Juhfah, bagi penduduk Najd adalah Qarn al-Manâzil dan bagi penduduk Yaman adalah Yalamlam. Mîqât-mîqât itu bagi mereka dan orang-orang yang melewati tempat itu walaupun bukan penduduk di situ, yaitu bagi yang akan menunaikan ibadah haji atau umrah. Dan bagi yang ada di luar tempat yang ditentukan maka mîqâtnya dari tempat ia mulai berniat mengerjakan sehingga penduduk kota Mekah dari kota Mekah itu sendiri. (H.r. al-Bukhârî dan Muslim)

Adapun mîqât kelima, Dzât 'Irq, telah ditentukan Rasulullah Saw. sebagaimana yang diterangkan dalam Hadis Aisyah Ra.:

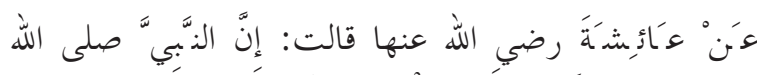

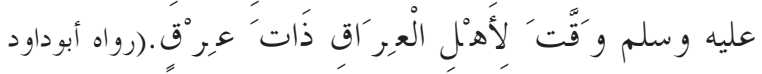

$$
\begin{aligned}
& \text { والنسائي) }
\end{aligned}
$$

Dari Aisyah Ra., sesungguhnya Nabi Saw. telah menetapkan mîqât makânî bagi penduduk Irak (yaitu) Dzât 'Irq. (H.r. Abû Dâwud)

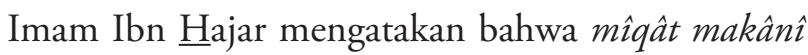
haji dan umrah bagi orang yang datang dari Madinah ialah Dzû al-Hulayfah yang terkenal dengan nama Bir Ali. Bagi yang datang dari Syam, Mesir dan Maghribi ialah Juhfah, dari Yaman ialah Yalamlam, dari Najd dan Hijaz ialah Qarn al-Manâzil, dari Masyriq ialah Dzât 'Irq. Bagi orang yang tidak punya mîqât dalam

33 'Irq artinya gunung kecil, terletak antara Dzat 'Irq dengan Mekah 2 markalah dan jaraknya 42 mill. Muhammad Amîn Ibn 'Abidîn, Hâsyiyah 'alâ al-Durr al-Mukhtâr, h. 522. Menurut Jumhur ulama miqât bagi penduduk Irak adalah Dzât 'Irq, tetapi menurut Imam Syâfî̀ miqât penduduk Irak lebih utama di al-'Aqî̀. Ibn Rusyd, Bidâyah al-Mujtahid wa Nihâyah al-Muqtashid, (Beirût: Dâr al-Fikr, 1990), h. 260. 
perjalanannya maka mîqâtnya disesuaikan dengan mîqât yang berlaku, baik melalui kendaraan darat maupun laut. Kalau tidak ditempuh dengan cara seperti itu maka mîqâtnya ialah dua marhalah dari Mekah. ${ }^{34}$

Syaykh Dâwud al-Fatanî berpendapat bahwa jika jemaah haji datang dari arah Yaman sebelah laut maka mîqâtnya adalah Yalamlam atau Jeddah dan yang datang dari arah darat Yaman dan Hijaz maka mîqâtnya adalah Qarn al-Manâzil ${ }^{35}$.

Bagi jemaah haji dan umrah yang menempuh jalan laut atau darat lalu tidak melalui salah satu mîqât yang lima maka ia hendaklah melakukan ihram jika melalui wilayah yang sejajar dengan mîqât yang paling dekat. Begitu juga orang yang naik pesawat, ia sudah berniat melakukan umrah atau hajinya di suatu wilayah yang diperkirakan segaris dengan mîqât terdekat. Jika tidak tahu garis yang sejajar dengan mîqât, untuk kehatihatian (ihtiyath) maka ia boleh melakukan ihram dari kejauhan. Sekiranya ia tidak yakin melewati mîqât dalam keadaan berihram maka melakukan ihram sebelum mîqât dibolehkan tetapi tidak boleh mengakhirkan. ${ }^{36}$

Ulama berbeda pendapat tentang hukum melakukan ihram sebelum sampai di mîqât yaitu: (1) Golongan Hanafiyyah berpendapat bahwa ketika seseorang akan melakukan ihram pada mîqât-mîqât maka sebaiknya ia menahan diri dari hal-hal yang melarangnya untuk melakukan ihram. Melakukan ihram sebelum sampai pada mîqât adalah lebih utama karena lebih banyak dan besar kesulitan yang ditanggung dan pahala tergantung pada kadar kesulitan yang dihadapi; (2) Golongan Syâfi'iyyah berpendapat bahwa ihram boleh dilakukan sebelum sampai di mîqât, dan (3) Golongan Mâlikiyyah dan Hanâbilah berpendapat bahwa melakukan ihram sebelum sampai di mîqât makânî hukumnya adalah makruh sebagaimana dimakruhkan ihram sebelum tiba waktunya mîqât zamânî̀, baik ihram haji maupun umrah atau kedua-duanya. Apabila ihram dilakukan maka hukumnya tetap $\operatorname{sah}^{37}$.

${ }^{34}$ Abû Muhammad 'Alî ibn Ahmad ibn Sa'îd Ibn Hazm, al-Maballî, Jilid VII, h. 70-72.

${ }^{35}$ Muhammad ibn Ismầîl Dâwud al-Fatanî, Mathla' al-Badrayn wa Majma' al-Bạrayn, h. 68.

36 Syams al-Dîn Abû al-Farj 'Abd al-Rahmân ibn Abî 'Umar Muhammad ibn Aḥmad al-Muqaddasî Ibn Qudâmah, al-Syarh $\underline{\text { al }}$ Kabîr 'alâ Matn al-Mughnî, (Dâr al-Kitab al-'Arabî, t.t.), Jilid III, h. 214-216. Ulama berbeda pendapat tentang melaksanakan ihram dari tempat yang sejajar dengan miqât. Sebagian ulama berpendapat wajib melakukan ihram di tempat tersebut dan sebagian berpendapat bahwa ihram tidak wajib di tempat tersebut karena tidak ada nas atau ijmak ulama yang menetapkannya. Abû Muhammad 'Alî ibn Aḥmad ibn Sâî̀ Ibn Hazm, al-Ma hallî, h. 73.

37 'Abd al-Jawwâd Khallâf, al- $\underline{H}$ ajj wa Mamnûatuhu, (Mesir: Dâr al-Dawliyyah al-Tsaqafiyyah, 2008), h. 36-37.
Pendapat bahwa melakukan ihram sebelum sampai ke mîqât hukumnya adalah makruh juga disampaikan

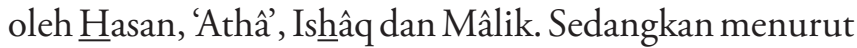

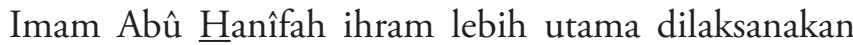
di negara masing-masing. Adapun 'Alqamah, Aswad dan 'Abd al-Rahmân berpendapat bahwa jika ihram dilakukan di negara masing-masing maka hukumnya haram, karena itu maka ihram harus dilaksanakan di mîqât $t^{38}$. Imam Syâfi'î dan para ulama dari Mazhab Syâfi'î berpendapat bahwa apabila seorang al-âfaqî sampai di mîqât dan bermaksud menunaikan haji dan umrah maka haram baginya melalui mîqât tanpa melakukan ihram. Hal ini berdasarkan ijmak para ulama ${ }^{39}$.

Orang al-âfaqî yang melewati mîqât untuk melakukan ibadah haji atau umrah tetapi tidak melakukan ihram maka ada dua solusi yang dapat dilaksanakan, yaitu pertama, ia harus kembali ke mîqât untuk melaksanakan ihram. Apabila melakukan hal ini maka tidak ada dam bagi orang tersebut. Ini adalah pendapat mayoritas ulama ${ }^{40}$.

Kedua, jika melakukan ihram setelah melewati mîqât maka ada beberapa pendapat, yaitu: (1) Menurut Imâm Mâlik, Imâm Ibn Mubarak dan Imâm Aḥmad bahwa ia wajib membayar dam, baik kembali lagi ke mîqât atau tidak ${ }^{41}$; (2) Menurut kalangan Mazhab Syâfî̀, jika kembali lagi ke mîqât maka ia tidak dikenakan dam kecuali sudah menunaikan amalan atau ibadah, seperti thawaf dan wuquf. Apabila telah melakukan amalan atau ibadah tersebut maka ia tetap harus membayar dam. Pendapat ini dipegang oleh Imâm Tsawrî, Imâm Abû Yûsuf, Muhammad dan Abû Tsawr ${ }^{42}$; (3) Menurut pendapat Imâm Abû Hanîfah, jika ia kembali lagi ke mîqât lalu mengucapkan niat umrah atau haji maka ia tidak wajib membayar dam. Namun jika tidak membaca talbiah ${ }^{43}$ untuk niat umrah atau haji maka ia

${ }^{38}$ Syams al-Dîn Abû al-Farj 'Abd al-Rahmân ibn Abî 'Umar Muhammad ibn Ahmad al-Muqaddasî Ibn Qudâmah, al-Syarh alKabîr 'alà Matn al-Mughnî, h. 222-223.

${ }^{39}$ Muhammad Mujâhid, "Nuzûl al-Damm 'alâ al-Mar'ah Atsnâ' Thawâf al-Ifâdhah," dalam Fatwa-Fatwa al-Azhar, ed. Zakariyyâ alBarri, (Mesir: Dâr al-Iftâ', 1980), h. 219.

${ }^{40}$ Abû Muhammad 'Alî ibn Aḥmad ibn Sa'î̀ Ibn Hazm, al-Mahallî, Jilid VII, h. 70.

${ }^{41}$ Syams al-Dîn Abû al-Farj 'Abd al-Rahnmân ibn Abî 'Umar Muhammad ibn Ahmad al-Muqaddasî Ibn Qudâmah, al-Syarh alKabîr 'alâ Matn al-Mughnî, h. 211, 213, 216 dan 218-220.

${ }^{42}$ Muhy al-Dîn Abî Zakariyyâ Yahyâ ibn Syaraf al-Nawâwî, I'ânah al-Thâlibîn, (Beirût, Dâr al-Fikr, 1997), Jilid II, h. 344.

${ }_{43}$ Ulama berbeda pendapat tentang hukum membaca talbiah. Menurut Imâm Syâfî̀ hukumnya Sunah muakkadah, menurut sahabat Imâm Mâlik hukumnya wajib dan dikenakan dam bagi yang meninggalkannya. Dan menurut al-Tsawrî dan Abû Hanîfah membaca talbiah merupakan syarat ihram. Syams al-Dîn Abû al-Farj 'Abd alRaḩmân ibn Abî 'Umar Muhammad ibn Ahmad al-Muqaddasî Ibn Qudâmah, al-Syarh al-Kabî̀ 'alâ Matn al-Mughnî, h. 256-257. 
harus membayar dam ${ }^{44}$. Berbeda dengan pendapat Abû Yûsuf dan Muhammad, murid dan pengikut Mazhab Hanafî mengatakan bahwa meskipun membaca talbiah ataupun tidak, ia tidak perlu membayar ${d a m^{45}}^{45}$ Dan apabila ia khawatir terlewatnya waktu haji jika kembali ke mîqât maka ia sebaiknya meneruskan ibadah haji dan umrah tanpa harus kembali ke mîqât, tetapi harus membayar dam. ${ }^{46}$

\section{Mîqât Makânî Jemaah Haji Indonesia}

Dalam masalah ihram pada mîqât makânî, Kementerian Agama berpendapat bahwa bagi jemaah haji Indonesia gelombang I (pertama ${ }^{47}$ mîqât makânînya adalah Bir Ali, sedangkan bagi jemaah gelombang II (kedua) ${ }^{48}$ adalah di atas udara pada garis sejajar dengan Qarn al-Manâzil, dapat berihram di King Abdul Aziz International Airport Jeddah (KAAIA) atau Asrama Haji Embarkasi Tanah Air ${ }^{49}$.

Imam Ibn Hajar membolehkan jemaah haji mengambil mîqât makânî di Jeddah dengan alasan jarak Jeddah ke Mekah dianggap sama dengan jarak Yalamlam $^{50}$ ke Mekah. Pendapat ini sesuai dengan prosedur tetap pengaturan pelaksanaan ibadah haji dan umrah oleh Kementerian Agama yaitu setibanya jemaah tiba di Jeddah menuju Madinah al- $\underline{\text { Hujjâj/ }}$ Wisma Haji kemudian mengenakan kain ihram untuk diberangkatkan ke Mekah dengan niat umrah dari Jeddah. ${ }^{51}$

Adapun jemaah yang tidak terus ke Mekah tetapi menuju Madinah terlebih dahulu maka mîqât-nya sama dengan jemaah haji yang datang dari arah Madinah yaitu di Dzû al- $\underline{\text { Hulayfah atau Bir Ali }}{ }^{52}$.

Organisasi Persatuan Islam (PERSIS) mempunyai pendapat yang berbeda dengan sistem yang

${ }^{44}$ Muhammad Amîn Ibn 'Abidîn, $\underline{H}$ âsyiyah 'alâ al-Durr al-Mukhtâr, Jilid II, h. 501.

${ }^{45}$ Abû Muhammad 'Alî ibn A $\underline{h}$ mad ibn Sa'îd Ibn $\underline{H}$ azm, al-Ma $\underline{\text { hallî̀, }}$ h. 73.

${ }^{46}$ Muhammad ibn Yûsuf ibn 'Îsâ, Syarh al-Nayl wa Syifâ' al-'Alîl, h. 20 .

${ }^{47}$ Gelombang pertama maksudnya adalah jemaah haji Indonesia yang langsung menuju Madinah kemudian mereka menuju Mekah untuk umrah haji bagi yang melakukan haji tamattu.

${ }^{48}$ Maksudnya jemaah haji Indonesia yang langsung pergi ke Mekah untuk menunaikan ibadah haji dan umrah.

49 Departemen Agama RI, Bimbingan Manasik Haji, (Jakarta: Direktorat Jenderal Bimbingan Masyarakat Islam dan Urusan Haji, 2001), h. 18 dan 60.

${ }^{50}$ Zayn al-Dîn al-Malibarî al-Fatanî, Fath al-Muî̀n Syarh Qurrah al-Ayn bi Muhimmah al-Dîn, (Beirût: Dâr al-Fikr, 1997), h. 343-344.

${ }^{51}$ Departemen Agama RI, Pelayanan Efektif Petugas Haji, (Jakarta: Direktorat Pembinaan Haji, 2008), h. 32.

${ }^{52}$ Muhammad ibn Ismầîl Dâwud al-Fatanî, Mathla’ al-Badrayn wa Majma’ al-Bahrayn, h. 68. diselenggarakan oleh Kementerian Agama. Ada dua mîqât makânî yang dilalui oleh jemaah haji dari Indonesia pada umumnya terutama yang menempuh jalur udara yaitu Qarn al-Manâzil (al-Sayl) bagi yang dijadwalkan terus masuk ke Mekah dari Indonesia dan Dzû al- Hulayfah (Bir Ali) bagi yang dijadwalkan akan ke Madinah terlebih dahulu. Setelah itu baru mereka masuk ke Mekah ${ }^{53}$.

PERSIS berpendapat bahwa jemaah haji Indonesia yang tidak mengambil mî̀ât di Qarn al-Manâzil atau Hadzwa $^{54}$ (garis sejajar) di antara dua mîqât maka mîqâtnya dianggap tidak sah, seperti ijtihad 'Umar Ibn al-Khattâb Ra.:

Setelah kedua negeri ini (Kufah dan Bashrah) menyerah, mereka datang kepada 'Umar Ibn al-Khattab dan berkata: "Wahai Amirul Mukminin, sesungguhnya Rasulullah Saw. telah menetapkan Qarn al-Manâzil sebagai mîqât bagi orang Najd tetapi itu terlalu jauh bagi kami. Dan jika pergi ke Qarn al-Manâzil dahulu itu menyulitkan kami”. 'Umar Ra. menjawab: "Telitilah $\underline{H}$ adzwa (tempat sejajar) dengan Qarn al-Manâzil di jalan yang kamu lalui'. Maka ditetapkanlah Dzât 'Irq sebagai mîqât bagi mereka" 55 .

Ijtihad 'Umar ini menegaskan bahwa orang yang akan melaksanakan ibadah haji atau umrah harus masuk melalui mîqât-mîqât yang telah ditentukan atau dari arah yang tidak menyusahkan.

Qarn al-Manâzil adalah berupa bukit yang terletak kurang lebih $94 \mathrm{~km}$ sebelah timur Mekah. Berihram dari Qarn al-Manâzil bukan berupa hal yang sulit apalagi dengan bantuan ilmu pengetahuan dan teknologi yang berkembang pesat saat ini.

PERSIS berpendapat bahwa jemaah haji yang mengambil mîqât dari Jeddah seperti yang dilaksanakan oleh Kementerian Agama adalah tidak sah karena mengambil mîqât dari tempat yang tidak ditentukan oleh syarak, kecuali kalau jemaah haji tersebut kembali ke mîqât yang telah dilewatinya ${ }^{56}$. Begitu juga jemaah haji dari Malaysia yang mengambil mîqât-nya di Jeddah adalah tidak sah karena bukan merupakan mîqât bagi

${ }^{53}$ Cara seperti ini juga dilakukan oleh para jemaah haji dari Malaysia. Johari Alias, Panduan Ibadah Haji, Umrah dan Ziarah, (Kuala Lumpur: Dar al-Nu'man, 1999), h. 11-12.

${ }^{54}$ Pengertian $\underline{h} a d z w a$ itu banyak seperti disebutkan dalam kamuskamus antara lain: garis sejajar, searah, berdekatan, di sisi, bertentangan dan yang lainnya, baik horizontal maupun vertikal. Penggunaan kata hadzwa tidak hanya berlaku dalam masalah haji tetapi juga masalah shalat. Shiddiq Amien, Tanya Jawab tentang Miqat dan Sa’i Ba'da Tawaf Ifadhah, (Tasikmalaya: Thulab, 1997), h. 17.

${ }^{55}$ Shiddiq Amien, Tanya Jawab tentang Miqat dan Sa’i Ba'da Tawaf Ifadhah, h. 16-17.

56 'Abd al-Muhsin ibn Muhammad al-Sâmihh, Khâlid ibn 'îsâ al'Âsirî dan Yûsuf ibn 'Abd Allâh al-Khatî, al-Bida' wa al-Mukhâlafah fi al- $\underline{H} a j j$, (Kerajaan Arab Saudi: Menteri Agama dan Ketua Majlis Tertinggi Agama Islam, 1427), h. 31. 
jemaah haji yang datang dari arah Asia, khususnya dari Indonesia dan Malaysia. Bagi mereka dikenakan dam tertib dan taqdîr ${ }^{57}$.

Kementerian Agama dan PERSIS juga berbeda pendapat tentang jemaah yang melewati mîqât tetapi tidak berniat ihram. Kementerian Agama berpendapat bahwa jemaah haji tidak boleh melewati mîqât tanpa melakukan ihram. Apabila melewatinya dan tidak berihram maka ia wajib kembali untuk melakukan ihram. Jika tidak kembali lagi maka hajinya tetap sah tetapi harus membayar dam dan berdosa apabila tidak ada halangan untuk kembali ke mîqât. Jika terdapat halangan seperti khawatir di jalan atau waktu yang telah mendesak maka dia tidak berdosa, baik masih ada lagi mîqât yang akan dilaluinya atau tidak ${ }^{58}$.

Sedangkan menurut pendapat PERSIS bahwa setiap orang yang melewati salah satu mîqât dan bermaksud menunaikan haji atau umrah maka tidak halal ia melewatinya kecuali telah berihram. Jika tidak berihram dari tempat itu maka tidak ada ihram, haji dan umrah baginya, kecuali ia kembali ke mîqât yang telah dilewatinya, lalu berniat ihram dari sana, maka sahlah pada saat itu ihram haji dan umrahnya ${ }^{59}$.

Kementerian Agama dan PERSIS mempunyai pendapat yang sama bahwa mîqât makânî bagi jemaah haji yang tinggal di Mekah atau yang telah berada di Mekah sebelum waktu haji dimulai adalah di kota Mekah. Dan untuk ihram umrah mereka adalah di luar kawasan Mekah seperti Tan'îm atau Ja'ranah ${ }^{60}$.

Demikian pula dengan jemaah haji tamattu dimana setelah selesai tahalul umrah mereka pergi ke Madinah. Apabila mereka masuk ke Mekah sebelum hari Tarwiyah maka ihram hajinya di tempat kediaman masing-masing, tetapi apabila masuk ke Mekah setelah hari Tarwiyah maka ihram hajinya di Dzû al- $\underline{\text { Hulayfah }}$ atau Bir Ali (mîqât yang dilaluinya) ${ }^{61}$. Apabila jemaah haji keluar dari Mekah dan kembali lagi setelah masuk

\footnotetext{
${ }^{57}$ Abdullah al-Qari bin Hj. Salleh, Bagaimana Nabi Saw. Berhaji dan Berumrah, (Kelantan: Pustaka Asa Kenali, 1984), 27.

${ }_{58}$ Muhammad Jawad Mughniyah, Figh Lima Mazhab: Jäfari, Hanafi, Maliki, Syafi'i, Hanbali, terj. Masykur A.B., Afif Muhammad dan Idrus al-Kaff, (Jakarta: Penerbit Lentera, 2008), h. 226.

59 'Abd al-'Azîz ibn 'Abd Allâh ibn Bazz, al-Tahquîq wa al-Idah li Katsîr min Masẩil al-Hajj wa al-'Umrah wa al-Ziyârah (Mekah: Menteri Urusan Agama, Waqaf, Da'wah dan Irsyad, 1425), h. 18.

${ }^{60}$ Johari Alias, Panduan Ibadah Haji, Umrah dan Ziarah, h. 11.

${ }^{61}$ Taufiq Rahman Azhar, "Keluar Miqat Bagi Muhrim Setelah Tahallul Bagi Tamattuk," dalam Kumpulan Keputusan Sidang Dewan Hisbah Persatuan Islam (Persis) tentang Akidah dan Ibadah, ed. Wawan Shofwan Shalehuddin, (Bandung: Persis Pers, 2008), h. 604, 610-611 dan 613 dan Usman Shalehuddin, "Jadwal Kepulangan Tiba Sebelum Tawaf Ifadhah Kerana Haid," dalam Kumpulan Keputusan Sidang Dewan Hisbah Persatuan Islam (Persis) tentang Akidah dan Ibadah, ed. Wawan Shofwan Shalehuddin, (Bandung: Persis Pers, 2008), h. 490.
}

waktu maghrib maka dia wajib berihram dari mîqât yang dilaluinya. Tetapi bila masuk mîqât sebelum maghrib maka ia wajib berihram dimana dia berada.

Menurut Kementerian Agama jemaah haji Indonesia yang langsung menuju Madinah, kemudian menuju Mekah untuk umrah haji bagi yang melakukan haji tamattu maka mîqât makânî-nya adalah Bir Ali dan bagi yang langsung pergi ke Mekah maka mîqât makânînya adalah di Qarn al-Manâzil, King Abdul Aziz International Airport Jeddah (KAAIA) atau Asrama Haji Tanah Air. Sedangkan menurut PERSIS, bagi jemaah haji Indonesia yang langsung menuju Mekah dan tidak mengambil mîqât di Qarn al-Manâzil atau di Hadzwa (garis sejajar) di antara dua mîqât maka mîqâtnya dianggap tidak sah. Dan jemaah yang ke Madinah terlebih dahulu lalu ke Mekah maka mîqâtnya adalah Bir Ali.

\section{Penutup}

Dari pemaparan di atas dapat disimpulkan bahwa Kementerian Agama tampak lebih lentur dan elastis dalam menanggapi fenomena yang terjadi karena jumlah jemaah haji yang semakin bertambah maka diambil langkah-langkah preventif agar tidak terjadi hal-hal yang tidak diinginkan dalam mengurus jemaah haji. Adapun PERSIS tetap berpendapat bahwa jemaah haji yang tidak mengambil mîqât di tempat yang telah ditentukan maka haji dan umrahnya tidak sah. Penulis lebih cenderung dengan pendapat kedua karena apabila mîqât di Qarn al-Manâzil atau $\underline{H} a d z w a$ masih memungkinkan bagi jemaah haji dan belum sampai pada tahap darurat untuk mîqât di Jeddah atau Asrama Haji Indonesia maka wajib baginya untuk mengambil

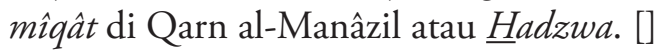

\section{Pustaka Acuan}

Âsirî, al-, 'Abd al-Muhsin ibn Muhammad al-Sâmih, Khâlid ibn 'Îsâ dan Yûsuf ibn 'Abd Allâh al-Khatî, al-Bida' wa al-Mukhâlafah fî al- $\underline{H} a j j$, Kerajaan Arab Saudi: Menteri Agama dan Ketua Majlis Tertinggi Agama Islam, 1427.

'Aynayn, al-, Badran Abû, Ushûl al-Fiqh al-Islâmî, Iskandariyah: Mu’assasah Syabâb al-Jâmi'ah, t.t..

Abbas, Sirajuddin, Sejarah dan Keagungan Madzhab Syafi'i, Jakarta: CV Pustaka Tarbiyah, 2006.

Alias, Johari, Panduan Ibadah Haji, Umrah dan Ziarah, Kuala Lumpur: Dar al-Nu’man, 1999.

Amien, Shiddiq, Tanya Jawab tentang Miqat dan Sa’i Baida Tawaf Ifadhah, Tasikmalaya: Thulab, 1997.

Anshârî, al-, Zakariyyâ ibn Muhammad ibn Aḥmad ibn Zakariyyâ, Fath al-Wahhâb bi Syarh Minhâj al- 
Thullâb, Beirût-Lubnân: Dâr al-Kutub al-'Ilmiyyah, 1998.

Azhar, Taufiq Rahman, "Keluar Miqat Bagi Muhrim Setelah Tahallul Bagi Tamattuk," dalam Kumpulan Keputusan Sidang Dewan Hisbah Persatuan Islam (Persis) tentang Akidah dan Ibadah, ed. Wawan Shofwan Shalehuddin, Bandung: Persis Pers, 2008.

Departemen Agama RI, Bimbingan Manasik Haji, Jakarta: Direktorat Jenderal Bimbingan Masyarakat Islam dan Urusan Haji, 2001.

---_-------, Pelayanan Efektif Petugas Haji, Jakarta: Direktorat Pembinaan Haji, 2008.

--.---.-----, 27 Tahun Departemen Agama (3 Januari 1973), t.tp.: Panitia HUT ke XXVII, t.t.

Falah, Syamsul, Pandangan Keagamaan Persatuan Islam: Studi atas Fatwa-Fatwa Dewan Hisbah Tahun 19831997", Laporan Penelitian IAIN Sunan Goenoeng Djati, Bandung, 1998.

Fatanî, al-, Muhammad ibn Ismầîl Dâwud, Mathla’alBadrayn wa Majma' al-Bahrayn, t.tp.: Maktabah wa Mathba'ah Muhammad al-Nahd wa Aulâduh, t.t.

-.------, Zayn al-Dîn al-Malibarî, Fath al-Mưîn Syarh Qurrah al-Ayn bi Muhimmah al-Dîn, Beirût: Dâr al-Fikr, 1997.

Ghânî, al-, Muhammad Ilyâs 'Abd, Târîkh Makkah alMukarramah: Sejarah Makkah, terj. Anang Rikza Mesyhadi Madinah Munawwarah: al-Rasheed Printers, t.t.

Hasan, $\underline{\text { Husayn }}$ Hâmid, al-Madkhal li Dirâsah al-Figh al-Islâmî, Kaherah: Dâr al-Nahdhah al-Arabiyyah, 1972.

Hasan, M. Ali, Perbandingan Mazhab, Jakarta: PT Raja Grafindo Persada, 2002.

Hassan, Ahmad, Ijmak-Qiyas-Mazhab-Taqlid, Bangil: Lajnah Penerbitan Pesantren PERSIS, 1984.

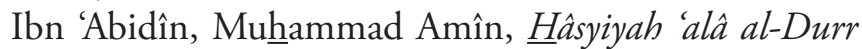
al-Mukhtâr Syarh Tanwîr al-Abshâr fi Fiqh Madzhab al-Imâm Abî Hanîfah al-Nuimân, Beirût: Dâr al-Fikr, t.t.

Ibn 'Îsâ, Muhammad ibn Yûsuf, Syarh al-Nayl wa Syifâ' al-Alîl, t.tp.: Maktabah al-Irsyâd, t.t.

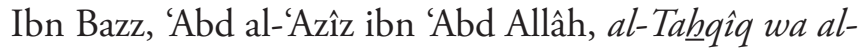
Idah li Katsîr min Masâil alal-Ziyârah, Mekah: Menteri Urusan Agama, Waqaf, Da'wah dan Irsyad, 1425.

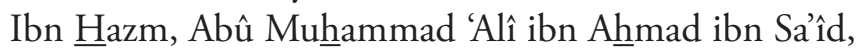
al-Mahallî, t.tp. Dâr al-Fikr, t.t.

Ibn $\mathrm{Hj}$. Salleh, Abdullah al-Qari, Bagaimana Nabi Saw. Berhaji dan Berumrah, Kelantan: Pustaka Asa Kenali, 1984.
Ibn Qudâmah, Syams al-Dîn Abû al-Farj 'Abd alRaḩmân ibn Abî 'Umar Muhammad ibn Aḥmad alMuqaddasî, al-Syarh al-Kabîr 'alâ Matn al-Mughnî, Dâr al-Kitab al-'Arabî, t.t.

Ibn Rusyd, Bidâyah al-Mujtahid wa Nihâyah alMuqtashid, Beirût: Dâr al-Fikr, 1990.

Kamiluddin, Uyun, Ijtihad sebagai Satu Usaha Penggali Hukum Islam dan Peranannya dalam Pembinaan Hukum Islam, Skripsi Fakultas Syariah, UNISBA, 1985.

----_-------, Menyorot Ijtihad Persis: Fungsi dan Peranan dalam Pembinaan Hukum Islam di Indonesia, Bandung: Tafakur, 2006.

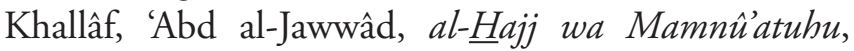
Mesir: Dâr al-Dawliyyah al-Tsaqafiyyah, 2008.

Muda, Abdul Latif, Perbahasan Sejarah Perundangan Islam dan Mazhab Fiqh, Kuala Lumpur: Pustaka Salam Sdn. Bhd, 2003.

Mughniyah, Muhammad Jawad, Fiqh Lima Mazhab: Ja'fari, Hanafi, Maliki, Syafi'i, Hanbali, terj. Masykur A.B., Afif Muhammad dan Idrus al-Kaff, Jakarta: Penerbit Lentera, 2008.

Mujâhid, Muhammad, "Nuzûl al-Damm 'alâ al-Mar'ah Atsnâ' Thawâf al-Ifâdhah," dalam Fatwa-Fatwa alAzhar, ed. Zakariyyâ al-Barri, Mesir: Dâr al-Iftâ’, 1980.

Nawâwî, al-, Muhy al-Dîn Abî Zakariyyâ Yahyâ ibn Syaraf, I'ânah al-Thâlibîn, Beirût, Dâr al-Fikr, 1997.

Qaththân, al-, Mannẩ Khalîl, Tầrîkh al-Tasyrî al-Islâmî, Beirût: Mu'assasah al-Risâlah, 1993.

Rosyada, Dede, Metode Kajian Hukum Dewan Hisbah PERSIS, Jakarta: Logos, 1999.

Sâyis, al-, Muhammad 'Alî, Târîkh al-Fiqh al-Islâmî, Damshiq: Dâr al-Fikr, 1999.

Shalehuddin, Usman, "Jadwal Kepulangan Tiba Sebelum Tawaf Ifadhah Kerana Haid," dalam Kumpulan Keputusan Sidang Dewan Hisbah Persatuan Islam (Persis) tentang Akidah dan Ibadah, ed. Wawan Shofwan Shalehuddin, Bandung: Persis Pers, 2008.

Siryati, al-, 'Abd al-Wadûd Muhammad, Târîkh al-Fiqh al-Islâmî wa Nazhariyyatuhu al-Âmmah, Beirût: Dâr al-Nahdhah al-'Arabiyyah, 1993.

Zakaria, Aceng, "Makna Ahlussunnah Waljamaah", dalam Kumpulan Keputusan Sidang Dewan Hisbah Persatuan Islam (PERSIS) tentang Akidah dan Ibadah, ed. Wawan Shofwan Shalehuddin, Bandung: Persis Pers, 2008. 